\title{
ФОРМУВАННЯ ПЕРШОЇ В УСРР ШКОЛИ КОНСТРУКТОРІВ ЕЛЕКТРИЧНИХ МАШИН (1920-І РОКИ)
}

\author{
Ігор Аннєнков \\ Національна наукова сільськогосподарська бібліотека НААН України (м. Київ, Україна) \\ e-mail: goalan93@gmail.com \\ ORCID: https://orcid.org/0000-0002-6642-8048
}

у статті встановлено, що форматом першої в УСРР школи конструкторів електричних машин стало відкрите у 1930 р. Відділення електромашинобудування вищого технічного навчального закладу при Харківському електромеханічному заводі. Ї̈̈ остаточне формування в Харкові, попри наявний на момент встановлення радянської влади в Україні потенціал щодо створення таких шкіл у низці їі регіонів, зумовлювалося провадженою урядом СРСР протягом 1920-х років промисловою політикою. Першість організації школи конструкторів електричних машин саме на промисловому підприємстві стала об'єктивним наслідком обраного способу наукового забезпечення вітчизняного електромашинобудівного виробництва.

Ключові слова: електромашинобудування, електрифікація, конструкторські кадри, промисловість, школа

Проваджений в Українській СРР протягом 1920-30-х років процес електрифікації вимагав створення надзвичайно широкого спектру електричних машин, що виводило цей напрям проектно-конструкторських робіт (ПКР) до числа найбільш поточне затребуваних напрямів такої діяльності. Нагальність інтенсифікації ПКР у сфері електромашинобудування посилювалася обраними в цей час урядом СРСР темпами індустріалізації радянської промисловості, основоположним моментом котрої і ставала електрифікація як процес заміни джерел забезпечення виробничих процесів механічною енергією з парових машин на електричні. Однак, у дорадянський період промислове виробництво електричних машин на теренах майбутнього Радянського Союзу здійснювалося іноземними фірмами, які провадили відповідні ПКР у своїх штаб-квартирах за рубежем 1 .

Отже, на початок 1920-х рр. розробка електромашин для вітчизняних фахівцівелектротехніків була ще доволі новою справою, що, зважаючи на затребувані у 1920-30-х рр. обсяги та швидкість профільних ПКР, апріорі ставило радянське електромашинобудування в залежність у цьому питанні від ступеня зацікавленості закордонних виготовлювачів ділитися своїми конструкторськими напрацюваннями. Між тим, через якість знань, що передавалися Радянському Союзу, указана залежність надавала спроможність впливати на хід процесів індустріалізації й електрифікації країни, тим самим стримуючи її науково-технічний розвиток. Таким чином, створення власної школи конструкторів електричних машин у 1920-30-х рр. для СРСР набуло характер стратегічного питання, для вирішення якого залучався й

\footnotetext{
${ }^{1}$ Аннєнков I.О. Електромашинобудування на українських теренах Росії напередодні революційних потрясінь та громадянської війни (1917р.) // Історія науки і біографістика. 2014. № 2. URL: http://inb.dnsgb.com.ua/2014-2/index.html
} 
український сегмент радянського електромашинобудування, як невід'ємна складова союзної профільної галузі.

Слід зауважити, що до початку 1930-х рр. українські електромашинобудівники успішно справилися з поставленими їм завданнями зі створення власної школи конструкторів електромашин, констатація якої в історіографії відбулася у дослідженнях O.Є. Тверитникової ${ }^{2}$, а також у колективній науковій праці під редакцією 0.0. Вознесенського 3 . Проте у згаданих історичних розвідках, внаслідок прийнятих у них територіальних меж досліджень і характеру поставлених завдань, сам процес формування української школи конструкторів електромашин висвітлюється фрагментарно та винятково стосовно харківських: Технологічного (XTI) та Електротехнічного (XETI) інститутів, а також Електромеханічного заводу (XЕМЗ). У цих наукових працях надаються неаргументовані переваги в першості у створенні української школи конструкторів електромашин кожному з означених закладів, у залежності від авторських уподобань, що, в купі із згаданою фрагментарністю, залишає тему даної наукової праці на сьогодні фактично недослідженою.

У той же час, з огляду на попередньо наведену роль електромашинобудування впродовж 1920-30-х рр., генеза української школи конструкторів-електромеханіків і досі являє з себе актуальне питання як з точки зору потреби у всебічному висвітленні обраного періоду в історії України, так і з позицій усвідомлення набутого досвіду з організації екстреної підготовки науково-технічних кадрів наукоємних галузей виробництва в умовах, коли ступень розвитку останніх уже набув своєї визначальності у подальшому розвитку суспільства в цілому, а попередніх заходів на формування кадрової складової наукового забезпечення роботи цих галузей не проводилося зовсім.

Зважаючи на окреслену актуальність теми наданого дослідження, його метою $\epsilon$ визначення регіональне-фахового формату першої української школи конструкторів електромашин і причин, що привели до його утворення наприкінці 1920-х років через вирішення завдань із встановлення загальної історичної картини їі ґенези та виявлення основних поточних факторів впливу на цей процес.

Необхідно зазначити, що відсутність на початку 1920-х років в електротехнічній промисловості УСРР конструкторів-електромеханіків ще не означала відсутність у республіці фахівців у сфері проектування електричних машин взагалі. 3 дорадянського періоду відповідною тематикою займалися українські науковціелектротехніки: під проводом Г.Є. Євреїнова - у катеринославських Гірничому (КГІ) та Єврейському політехнічному інститутах (КЄПІ)4; очолювані П.П.Копняєвим - у

\footnotetext{
2 Тверитникова 0.Є. Внесок учених Харківського технологічного та електротехнічного інститутів у розвиток електротехнічної галузі України (1885-1950рр.): дис... канд. іст. наук: 07.00.07 / Національний технічн. ун-т «ХПІ». Харків, 2009. 267 с.; Тверитникова 0.Є. Науково-дослідна робота в галузі електроприводу в Харківському електротехнічному інституті (30-40 роки XX ст.) // Актуальні питання історії науки і техніки: 7 Всеукр. наук. конф. Київ, 2-3 жовт. 2008 р. Київ, 2008. С. 98100; Тверитникова 0.Є. Розвиток мережі підготовки кадрів для електротехнічного промислового комплексу // Вісн. Нац. техн. ун-тету «ХПІ»: Автоматика та приладобудування. Харків, 2007. № 37. C. $90-93$.

3 Очерк истории Харьковского электромеханического завода: В 2-х ч. / В.В. Суздальцев и др. Харьков, 1965. Ч. 2. 1918-1964 гг. 260 с.

${ }^{4}$ Савчук В.С., Сюх А.В. Георгій Євгенович Євреїнов - знакова постать гірничої науки // Наддніпрянська Україна: історичні процеси, події, постаті. 2012. Вип. 10. С. 193-204.
} 
Харківському технологічному інституті (XTI)5; згуртовані навколо 0.0. Скоморохова - у Київському політехнічному інституті (КПI)6. Однак кількість таких українських учених у цей період значно поступалася чисельності відповідних фахівців історично зосереджених у Москві та Петрограді, а їх робота стосувалася винятково теорії електричних машин, оскільки, як йшлося попередньо, конструювання такого роду техніки відбувалося, здебільшого, за кордоном. По встановленню ж радянської влади та націоналізації електромеханічних підприємств питання підготовки конструкторських кадрів для електромашинобудівної галузі, внаслідок втрати відповідних зв'язків з іноземними материнськими компаніями, почало набувати своєї нагальності. Усвідомлюючи цей момент, до 1921 р. керівництва всіх існуючих на той час технічних вишів УСРР, - КПІ, Одеського політехнічного інституту (ОПI), ХТІ та КГІ, запровадили на своїх електротехнічних факультетах і відділеннях дисципліни з основ проектування електричних машин ${ }^{7}$.

Означене широке розгортання в Україні заходів із підготовки конструкторів електричних машин, попри обмежену кількість обізнаних на теоретичних засадах їх проектування викладачів, малися цілком виправдані причини. Так, у спадок від царату УСРР отримала найпотужніший з усіх електротехнічних підприємств у колишній імперії, перейменований в «Електросилу № 1», Харківський електромеханічний завод (ХЕМЗ) колишнього Російського товариства «Загальної електричної кампанії» (РТ «ЗЕК»)8. Окрім цього гіганту, в Харкові знаходилися середні за розмірами електромеханічні заводи колишніх РТ «Сіменс-Шукерт» і РосійськоФранцузького товариства9 , а також добре механізовані ремонтно-виробничі майстерні Монтажно-будівельного бюро (МББ) РТ «ЗЕК» $з$ чисельністю промислового персоналу близька 40 чол. ${ }^{10}$, що на початку ХХ ст. відповідало вимогам до невеликих заводів. Майже у шість разів більшим від Харківського було Миколаївське МББ РТ «ЗЕК»11, а поряд 3 ним знаходився новий, тільки-но побудований, але не до кінця оснащений виробничим устаткуванням електромеханічний завод «Темвод»12. У Катеринославі було розпочато будівництво електромеханічного заводу «Вікерс»13, а ще три заводи, котрі у своїй виробничій програмі разом із засобами зв'язку мали електричні машини, розташовувалися в Києві (два) та Одесі14. Тож, наявна в УСРР на початок 1920-х років загальна кількість територіальне розосереджених електромеханічних підприємств, на тлі розгортання за планом ДЕЕЛРО інтенсивної електрифікації країни, за одночасної втрати традиційного зарубіжного наукового забезпечення електромашинобудівного виробництва, природно вимагала створення за-

\footnotetext{
5 Ткаченко С.С. Внесок П.П. Копняєва у розвиток вітчизняної електротехніки // Актуальні питання історії науки і техніки: 5 Всеукр. наук. конф. Київ, 19-20 жовт. 2006 р. Київ, 2006. С. 45-48.

6 Видолоб Ю.Ф., Сенько В.І. Кафедра теоретичних основ електротехніки // Факультет електроенерготехніки. Нариси історії: Зб. наук. праць. Київ, 1998. С. 53-75.

7 Держархів Одеської області (далі - ДАОО). Ф. Р-126. Оп. 1. Спр. 147. 93 арк.; Держархів міста Києва (далі - ДАМК). Ф. Р-308. Оп. 1. Спр. 48. 129 арк.; Держархів Харківської області (далі - ДАХО). Ф. Р-1682. Оп. 1. Спр. 83. 23 арк.; Савчук В.С., Сюх А.В. Вк. пр.

8 Очерк истории Харьковского электромеханического завода...

${ }_{9}^{9}$ Аннєнков I.O. Вк. пр.

10 ДАХО. Ф. 349. Оп. 1. Спр. 196. 50 арк.

11 Держархів Миколаївської області (далі - ДАМО). Ф. 302. Оп. 1. Спр. 28.407 арк.

12 ДАМО. Ф. 301. Оп. 1. Спр. 1.135 арк.

13 Держархів Дніпропетровської області. Ф. 701. Оп. 1. Спр. 1. 223 арк.

14 Васильев М.П., Потресов В.Е., Тейтель И.В. Промышленность Украины в 1921 году. Харьков: УCHX, 1922. $200 \mathrm{c}$.
} 
гальнореспубліканської мережі з підготовки конструкторів відповідного фаху, що й почало практично здійснюватися з 1921 р.

Між тим, унаслідок викликаної громадянською війною та зміною суспільного устрою кризи промислового виробництва, попит на нові електромашини у першій половині 1920-х років в Україні був невеликим i, попри вживані заходи 3 відновлення народногосподарського комплексу, зростав дуже повільно. Дані обставини зумовлювалися кількома чинниками, сукупна дія яких привела до значного скорочення ринку споживання електричних машин і, як результат, закриття або перепрофілювання, або зосередженні виключно на ремонтних роботах більшості українських електромеханічних підприємств. Одним з цих чинників було те, що стратегія радянської влади у питанні подолання кризи передбачала першочергове провадження відповідних заходів у «старих» промислових регіонах, розташованих у Центральній та Північно-Західній Росії, а також у тих українських регіонах, де була сконцентрована промисловість з видобутку сировинних ресурсів та виробництва напівфабрикатів. Звідси, велика частка українських підприємств державного сектору з кола тих, що не входили до числа останніх, за виключенням закладів сільськогосподарського машинобудування, втратили поточну можливість здійснювати свою діяльність, а отже - вийшли із ринку споживання електромашин ${ }^{15}$.

Іншим чинником дуже повільного зростання попиту на електричні машини в УСРР у першій половині 1920-х років стала, почасти ситуативно виправдана, а в цілому - зумовлена ідеологією запровадженого «радянського» способу господарювання, політика концентрації організованого за масовим типом виробництва на великих промислових закладах ${ }^{16}$. Через неї в Україні державні дрібні та середні підприємства навіть у галузях виробництва сировини та напівфабрикатів більшою чисельністю були позбавлені фінансування, припинили функціонування та були законсервовані 17 , а в машинобудуванні обсяг таких заводів склав 77\% ${ }^{18}$. Наслідком указаної ж політики стало масштабне та слабо контрольоване переміщення обладнання з законсервованих підприємств на працюючі19, що привело до значних обсягів вилучення останніми з зупинених заводів як електрифікованого устаткування, так і безпосереднє електричних машин. Тож, з огляду на отриману залишеними працювати державними заводами можливість постачати себе електромеханікою, нехай і вживаною, але у великих, практично безоплатних і неконтрольованих обсягах, коло потенційних споживачів електричних машин у республіці звузилося ще більше, не зважаючи на те, що частку зупинених підприємств з усіх промислових галузей було передано в оренду недержавному сектору економіки. Будучи ідеологічне неприйнятною радянському способу господарювання, недержавна сфера сприймалася радянською владою як тимчасове явище, з-за чого її доступ до кредитних ресурсів був значно ускладненим, а самі ці ресурси коштували їй у чотири рази дорож-

\footnotetext{
15 Лапиров-Скобло М. Русская промышленность в 1923 году: в 2-х ч. Москва: ВСНХ, 1924. Ч. 1. Отчет II съезду Советов СССР. 161 с.

16 Центральний держархів вищих органів влади і управління (далі - ЦДАВОВУ) України. Ф. Р-337. Оп. 1. Спр. 10559.50 арк.

17 ЦДАВОВУ України. Ф. Р-2. Оп. 1. Спр. 812. 131 арк.

18 Васильев М.П., Потресов В.Е., Тейтель И.В. Вк. пр.

19 Центральний держархів громадських об'єднань (далі - ЦДАГО) України. Ф. 1. Оп. 20. Спр. 2502. 307 арк.
} 
че від державного сектору20. У результаті цього, провадити більш-менш глибоку електрифікацію недержавний сектор промисловості був нездатним i, з огляду на його до того ж незначну питому вагу в загальному валі виробництва, скласти потрібне для підтримання всіх наявних у республіці електромеханічних заводів середовище споживання електричних машин за рахунок недержавної індустрії, бодай у робочому стані, не уявлялося можливим.

3 наведених причин, до 1923 р. ситуація із споживанням в Україні електромашин погіршилася настільки, що урядом СРСР було підняте питання стосовно закриття найбільшого у країні електромеханічного заводу «Електросила № 1» через неможливість охопити його замовленнями в обсягах, здатних забезпечити бодай заробітну платню постійному промислове-виробничому персоналу 21 . У той же час, Ленінградський електромеханічний завод «Електросила» (колишній «СіменсШукерт») i Московський електромеханічний завод «Динамо» (колишній «Вестінгауз») працювали нехай і не на повну потужність, але з поступовим і неухильним збільшенням виробничого навантаження. Даний момент став ключовим для зняття радянським урядом з порядку денного питання щодо закриття «Електросили № 1», оскільки передбачувана на 1924 р. динаміка зростання замовлень двом вище згаданим російським заводам не дозволяла гарантувати задоволення ними того попиту на електромашини, який мав би утворитися при одночасних: остаточному виході з кризи «старих» промислових районах і початку такого процесу в Україні. Тож, протягом 1924 р. були ухвалені прямо протилежні первинним планам заходи із додаткового обмеження виробництва електричних машин на будь-яких українських електротехнічних підприємствах, окрім «Електросили № 1», унаслідок яких близько 95\% обсягів випуску електромашин в УСРР було зосереджено на цьому заводі 22.

Таким чином, до середини 1920-х років Харків став єдиним в УСРР осередком промислового виготовлення електричних машин і створення у республіці мережі закладів з підготовки їх конструкторів почало втрачати свій сенс. Звідси, до 1926 р. лише у XTI конструювання електромашин залишилося одним з фахів підготовки спеціалістів ${ }^{23}$, у решті ж технічних вишів відповідний напрям не отримав розвитку в спеціальність і залишився навчальною дисципліною, покликаною підвищити ступінь теоретичної підготовки електромеханіків-експлуатаційників ${ }^{24}$. Однак слід зауважити, що на відміну, наприклад, від московських технічних вишів - Вищого технічного училища, Ломоносовського механіко-електротехнічного інституту й Інституту Каган-Шабшая, у XТI цілеспрямованої підготовки конструкторів електричних машин у цей час не проводилося і практична спеціалізація інженерівелектротехніків визначалася дипломним проектом ${ }^{25}$. Отже, характер підготовки тих конструкторів електромашин, які випускалися XTI, був загальнотеоретичним, що, через відсутність належної обізнаності у процесах виробництва, специфіці сфер застосування та конкретних методиках розрахунків електричних машин, робило

\footnotetext{
20 Волосник Ю.П. Нова буржуазія України та розвиток приватнопідприємницької діяльності на фінансовому ринку в роки НЕПу. Харків: НМЦ «СД», 2002. 384 с.

21 ДАХО. Ф. П-1. Оп. 1. Спр. 896. 44 арк.

22 Очерк истории Харьковского электромеханического завода...

23 ДАХО. Ф. Р-1682. Оп. 1. Спр. 183. 191 арк.

24 ДАМК. Ф. Р-308, Оп. 1. Спр. 409. 230 арк.; ДАОО. Ф. Р-126. Оп. 1. Спр. 235. 43 арк.

25 ДАХО. Ф. Р-1682. Оп. 1. Спр. 191. 22 арк.
} 
рівень практичної кваліфікації таких спеціалістів доволі низьким. Окрім того, внаслідок спаду електромашинобудівного виробництва в УСРР, що тривав практично всю першу половину 1920-х років, суттєвої потреби у конструкторах електромашин не було, а це не сприяло зростанню кількості бажаючих отримати відповідну спеціалізацію й обсяг випускників такого фаху навіть у 1927 р. не перевищував 6\% загального обсягу випускників Електротехнічного факультету XETI26.

Між тим, у результаті концентрації електромашинобудівного виробництва, помноженого на розгортання процесу виводу з кризи українського сегменту союзної індустрії, вже у 1925 р. завод «Електросила № 1» не впорювався із виконанням замовлень на виробництво електричних машин ${ }^{27}$. Ситуація ускладнювалася тим, що, окрім участі у провадженні електрифікації української промисловості, перейменована у Державний електрозавод (ДЕЗ) «Електросила № 1» залучалася до Шестирічної (1927-1932 рр.) програми розбудови військово-морських сил СРСР28. Даний крок був викликаний тим, що ще у дореволюційний час ДЕЗ був основним у Російській імперії постачальником військово-морської електротехніки, тож на ньому мався суттєвий досвід як не конструювання, то, принаймні, виготовлення специфічного морського електроустаткування 29 . Тож темпи зростання виробничого навантаження на підприємство неочікувано для уряду перевищили можливості наявної на ньому матеріально-технічної бази. Через це терміново було проведено деконцентрацію республіканських електромашинобудівних потужностей шляхом розконсервації та пуску колишнього заводу «Сіменс-Шукерт», який отримав назву Харківський електрозавод (XЕ3), а також розширення виробничих площ Харківського МББ колишньої «ВЕК», що, як ДЕЗ і ХЕЗ, увійшло до створеного в 1925 р. Державного Союзного електротехнічного тресту (ДЕТ) його Харківським відділенням (ХВ ДЕТу) ${ }^{30}$.

Нарощування виробничих потужностей українського електромашинобудування у вказаний спосіб зумовлювалося тимчасовістю відходу уряду від принципу концентрації виробництва електричних машин. Даний відхід здійснювався ситуативно і тривав до кінця 1920-х років, коли темпи розвитку матеріально-технічної бази ДЕЗу стали відповідними темпам збільшення виробничого навантаження на український сегмент профільної галузі. На рубежі ж 1930-х - 1940-х років ХЕЗ був перепрофільований на випуск засобів зв'язку, а промислові площі ХВ ДЕТу - приєднані до ДЕЗу, що знов зробило останній монополістом в українському електромашинобудуванні 31 . Первинна ж тимчасовість здійснених протягом 1926-1927 рр. заходів зі збільшення кількості виробників електромашинобудівної продукції в УСРР стала причиною того, що з усіх промислових закладів організація профільної конструкторської школи зберігала свою актуальність тільки для ДЕЗу. Хоча з позиції української фахової науково-технічної спільноти, озвученій директором ХВ ДЕТу (який одночасно був викладачем ХТІ) А.Л. Матвєєвим на Першому Українському Енергетичному з'їзді 20 квітня 1928 р., i підтриманій делегатами цього з'їду, заходи такого роду повинні були мати всеук-

\footnotetext{
26 ДАХО. Ф. Р-1682. Оп. 1. Спр. 205. 104 арк.

27 ДАХО. Ф. П-1. Оп. 1. Спр. 1180. 96 арк.

${ }^{28}$ Annenkov I. The Kharkov Electromechanical Plant contribution to the soviet military submarine fleet formation in the 1920-1941 // Colloquium, 2019. No. 3. Pp. 147-164.

29 ДАХО. Ф. 348. Оп. 1-17.

30 Аннєнков І.О. Організаційні структури електромашинобудівної галузі в Українській РСР у 19221941 pp. // Історія науки і техніки. 2015. № 7. С. 3-20.

31 Ibidem
} 
раїнський масштаб 32 . Тобто, з точки зору науково-технічної спільноти, майбутня організація підготовки конструкторів електричних машин у республіці мала бути масштабною та відбуватися в українських технічних вишах.

Між тим, в УСРР з 1927 р. підготовка конструкторів у галузі електромашинобудування почала зосереджуватися на ДЕЗі, що зумовлювалося низкою причин практичного характеру. Насамперед, як уже згадувалось, на середину 1920-х років концептуально радянським урядом не розглядалося іншого шляху розвитку електромашинобудування в Україні, ніж концентрація основного валу відповідного виробництва на ДЕЗі, що звужувало масштаби використання конструкторів профільної техніки, по суті, до єдиного, нехай і гігантського, підприємства. Таким чином, розпорошення осередків підготовки конструкторських кадрів всією УСРР приводило б як до послаблення щільності науково-технічних зв'язків з ДЕЗом їх найбільш географічно віддаленої від цього заводу частки, так і до посилення соціальнопобутових проблем, пов'язаних із облаштуванням випущених такими осередками спеціалістів у Харкові. Тож попереднє укладання в УСРР територіального розташування осередку підготовки профільних конструкторів у Харкові, на другу половину 1920-х років отримало свою повну організаційне-економічну доцільність, принаймні - у межах обраної концепції галузевої промислової політики. Даний чинник знімав питання щодо централізованої організації відповідних осередків у будь-яких інших регіонах УСРР, що наприкінці 1920-х років остаточно закріпило Харків як місце, де мала зосередитися підготовка конструкторів для електромашинобудування республіки.

Однак обставини, за яких з 1925 р. відбувався розвиток електромашинобудування в Україні, не сприяли створенню осередку підготовки конструкторів електричних машин саме у XTI, незважаючи а ні на вже розпочате тут викладання основ проектування цих засобів, а ні на нагромаджені інститутськими вченими певні відповідні теоретичні здобутки. Так, з 1925 р. до 1928 р. обсяги виробництва електричних машин українськими підприємствами ДЕТу зросли майже в три рази, але, у той же час, імпорт такої техніки також збільшився з 37\% до 39\% від усіх її обсягів надходження на внутрішній ринок 33 . При цьому, якщо у 1925 р. імпорт зумовлювався, переважно, недостатньою продуктивністю українського електромашинобудування, то в 1928 р. - невідповідністю більшості виробленої номенклатури продукції поточно-перспективним потребам споживачів 34 . Однак і зростання продуктивності електромашинобудівного виробництва було досягнуто не внаслідок відповідного доробку вітчизняних учених, а завдяки укладеному в 1926 р. Договору про науковотехнічну співпрацю між ДЕТом та AEG 35 . Згідно цьому Договору, німецький концерн брав на себе зобов'язання, у першу чергу, впровадити на радянських електромеханічних підприємствах сучасні виробничі технології, що, власне, й було здійснено 36.

\footnotetext{
32 ЦДАВОВУ України. Ф. Р-797. Оп. 1. Спр. 1. 288 арк.

33 ЦДАГО України. Ф. 1. Оп. 20. Спр. 2506. 43 арк.

34 Ibidem

35 Аннєнков І.О. Концепція науково-технічної політики в електромашинобудуванні Української СРР у період НЕПу (1921-1931 pp.) // Evropský filozofický a historický diskurz. 2016. Sv. 2. Vyd. 2. S. 44-50.

36 Новиков М.В. Иностранный капитал в советской электротехнической промышленности сильных токов: формы привлечения и результаты использования (1920-1932 гг.): автореф. дис... канд. эконом. наук: 08.00.01 «Экономическая теория» / Волгоградский государственный університет. Волгоград, 2006. 21 c.
} 
Проте підняти технічний рівень профільних виробів до відповідного поставленим завданням з електрифікації радянського суспільства AEG у повному обсягу не міг, оскільки на цей час сам уже значно відставав від найсучасніших досягнень британських та американських електротехнічних фірм ${ }^{37}$.

Попри наявність можливості ознайомлення бодай із сучасними технологіями електромашинобудівного виробництва та принципами конструювання тих синхронних машин AEG, технічний рівень котрих ще не втратив своєї актуальності, i виготовлення яких було налагоджене на ДЕЗі, вчені XТІ початково обмежилися проведенням під керівництвом М.Ф. Перевозського, на основі узагальнення досвіду цього концерну, оптимізації номенклатури виготовлюваних вітчизняною промисловістю електромоторів 38 . На ДЕЗі ж, за ініціативи О.Я.Бергера (який, до речі, за сумісництвом працював викладачем на Електротехнічному факультеті XTI) 1 жовтня 1927 р. було створено Бюро досліджень синхронних машин ${ }^{39}$, в якому науково-технічні працівники заводу зайнялися саме ретельним вивченням конструкторсько-технологічного досвіду AEG. Тобто, XTI, незважаючи на відсутність власного практичного доробку в галузі конструювання електричних машин, не було проявлено належної ініціативи в питанні запозичення відповідних знань, попри наявність такої можливості. Звідси, з 1928 р. ДЕЗ у питанні обізнаності своїх науково-технічних працівників на конструюванні електричних машин почав отримувати перевагу перед науково-педагогічними працівниками XTI.

31929 р. ця перевага значно посилилася через укладання Всесоюзним електротехнічним об’єднанням, що прийшло на заміну ДЕТу, чергового Договору про науково-технічну співпрацю, на цей раз з однією із провідних світових електротехнічних компаній - американською GEC40. На XEMЗі, в який було перейменовано ДЕ3, до поглибленого вивчення конструкцій найсучасніших електричних машин, а також методів їх розробки та впровадження до виробництва вдалися не лише фахівці раніше згаданого Бюро, а й Спеціального сектору проектно-технологічного відділу заводу (ПТВ), організованого на задовольняння потреб радянських ВМС у відповідному електротехнічному обладнанні41. Отже, коли до XTI через працюючих у ньому за сумісництвом науково-технічних співробітників ХЕМЗу тільки-но почала надходити узагальнена інформація щодо принципів конструювання електричних машин, застосованих одним з їх виробників (AEG), самі ці співробітники вже освоювали таку інформацію стосовно іншого виробника (GEC).

Даний ефект випередження в отриманні інформаційного забезпечення за наявної термінової потреби у формуванні вітчизняної школи конструкторів електричних машин і послужив основною підставою для організації такої на ХЕМЗі шляхом фундації у жовтні 1930 р. при заводі спеціалізованого вищого технічного навчального закладу (ВТНЗ) ${ }^{42}$. Контингент студентів спочатку склав 54 чол. ${ }^{43}$, 3 яких 31 чол.

\footnotetext{
37 Ibidem

38 ЦДАВОВУ України. Ф. Р-797. Оп. 1. Спр. 7. 79 арк.

39 ЦДАВОВУ України. Ф. Р-797. Оп. 1. Спр. 194. 6 арк.

40 Новиков М.В. Вк. пр.

41 Аннєнков I.O. Організація системних науково-дослідних і дослідно-конструкторських робіт 3 оборонної тематики на Харківському електромеханічному заводі (1920-і - 1930-і роки) // Людина і техніка у визначних битвах світових воєн XX століття: Міжнар. наук. конф. Львів, 1517 червня 2017 р. Львів. 2017. С. 15-16.

42 Очерк истории Харьковского электромеханического завода...

43 ЦДАВОВУ України. Ф. Р-1252. Оп. 1. Спр. 13. 66 арк.
} 
готувалися як конструктори електромашин, 11 чол. - як конструктори електроапаратів, а ще 12 чол. - фахівцями з холодної обробки металів ${ }^{4}$. Заняття проводилися фахівцями ХЕМЗу, які за сумісництвом були й викладачами XTI, а керівником цього ВТНЗ став провідний спеціаліст Спеціального сектору ПТВ заводу Г.І. Штурман, також за сумісництвом - викладач Електротехнічного факультету XTI45.

Таким чином, у 1930 р. організацією у ВТНЗ ХЕМЗу цілеспрямованої підготовки конструкторів електричних машин було створено першу в УСРР відповідну школу, що не дозволяє вважати такою ХТІ через суперечність спорадичності випуску таких фахівців цим вишем системності поняття «школа». Причини ії організації у Харкові полягали як у кризі електромашинобудування в Україні на початку 1920-х років, так і застосованих урядом СРСР заходах з по-територіального виходу із неї, помножених на запровадження політики концентрації промислового виробництва у цілому. Як наслідок, первинно отримані УСРР у спадок від Російської імперії регіональні електромашинобудівні потужності, у своїй переважній більшості, втратили перспективу розвитку і, відповідно, потребу у конструкторських кадрах. Виняток склав ХЕМЗ, як самий потужний електромеханічний завод у СРСР, неухильний розвиток котрого передбачав таке ж неухильне зростання його потреб у конструкторських кадрах, що й створило передумови створення першої української школи конструкторів електричних машин у Харкові.

Головною ж причиною організації системної підготовки конструкторів електромашин саме на промисловому підприємстві стала термінова потреба в означених спеціалістах за відсутності належних як досвіду відповідного навчання у регіональних технічних вишів, так і досвіду конструювання електричних машин в українських електромеханічних заводів. За таких обставин, єдиною можливістю для вітчизняної профільної галузі забезпечити вимоги провадженого радянським урядом процесу електрифікації до технічного рівня затребуваних електричних машин ставало пряме запозичення їх конструкцій у провідних зарубіжних виробників. Унаслідок застосування цього варіанту наукового забезпечення, виробничники отримали першочерговий доступ до сучасних методів конструювання, а отже - й першочергову можливість для їх аналізу та синтезу, що, за умови налагодження способу безпосереднього передавання ними отриманих знань, дозволяло значно пришвидшити процес підготовки кваліфікованих конструкторських кадрів. Даний процес ставав ще більш швидким при залученні до проведення згаданих запозичень під проводом заводських фахівців самих студентів, що на тлі нагальності проблеми конструкторських кадрів зіграло ключову роль в організації відповідної школи саме на промисловому підприємстві.

\section{REFERENCES}

Annienkov, I.O. (2014). Elektromashynobuduvannia na ukrainskykh terenakh Rosii naperedodni revoliutsiinykh potriasin ta hromadianskoi viiny (1917 r.) [Electrical engineering in the Ukrainian territories of the Russian Empire on the eve of revolutionary upheavals and civil war (1917)]. Istoriia nauky i biohrafistyka, 2, Retrieved from: http://inb.dnsgb.com.ua/2014-2/index.html/ [in Ukrainian].

Annienkov, I.O. (2015). Orhanizatsiini struktury elektromashynobudivnoi haluzi v Ukrainskii RSR u 1922-1941 rr. [Organizational structures of the electric machine-building industry in the Ukrainian

44 ЦДАВОВУ України. Ф. Р-1252. Оп. 1. Спр. 28. 97 арк.

45 Аннєнков І.О. Наукове забезпечення виробництва електричних машин на Харківському електромеханічному заводі у 1919-1940 рр.: критика історіографії // Дослідження з історії і філософії техніки. 2019. Т. 28. № 2. С. 70-76. 
SSR in 1922-1941]. Istoriia nauky i tekhniky, 7, 3-20 [in Ukrainian].

Annienkov, I.O. (2016). Kontseptsiia naukovo-tekhnichnoi polityky v elektromashynobuduvanni Ukrainskoi SRR u period NEPu (1921-1931 rr.) [The concept of scientific and technical policy in electrical engineering of the Ukrainian SSR during the NEP (1921-1931)]. Evropský filozofický a historický diskurz, Sv. 2, (2), 44-50 [in Ukrainian].

Annienkov, I.0. (2017). Orhanizatsiia systemnykh naukovo-doslidnykh i doslidno-konstruktorskykh robit z oboronnoi tematyky na Kharkivskomu elektromekhanichnomu zavodi (1920-i - 1930-i roky) [Organization of systemic research and development work on defense topics at the Kharkov Electromechanical Plant (1920s-1930s)]. Abstracts of Papers: Liudyna i tekhnika u vyznachnykh bytvakh svitovykh voien XX stolittia. Lviv. Pp. 15-16 [in Ukrainian].

Annenkov, I. (2019). The Kharkov Electromechanical Plant contribution to the soviet military submarine fleet formation in the 1920-1941. Colloquium, 3, 147-164 [in English].

Annienkov, I.O. (2019). Naukove zabezpechennia vyrobnytstva elektrychnykh mashyn na Kharkivskomu elektromekhanichnomu zavodi u 1919-1940 rr.: krytyka istoriohrafii [Scientific support for the production of electric machines at the Kharkiv electromechanical plant in 1919-1940: criticism of historiografy]. Doslidzhennia z istorii i filosofii tekhniky, Vol. 28 (2), $70-76$ [in Ukrainian].

Lapirov-Skoblo, M. (1924). Russkaia promyshlennost v 1923 godu [Russian industry in 1923]. Vol. 1: Otchet II siezdu Sovetov SSSR [Report to the Congress of Soviets of the USSR]. Moskva: VSNKh [in Russian].

Novikov, M.V. (2006). Inostrannyi kapital v sovetskoi elektrotekhnicheskoi promyshlennosti silnykh tokov formy privlecheniia i rezultaty ispolzovaniia (1920-1932 gg.) [Foreign capital in the Soviet electrotechnical industry of strong currents: forms of attraction and results of use (1920-1932)] (Extended abstract of Candidate's thesis). Volgograd: Volgogradskii gosudarstvennyi universitet [in Russian].

Savchuk, V.S. \& Siukh, A.V. (2012). Heorhii Yevhenovych Yevreinov - znakova postat hirnychoi nauky [Georgy Evgenievich Evreinov - an iconic personality in mining science]. Naddniprianska Ukraina: istorychni protsesy, podii, postati, 10, 193-204 [in Ukrainian].

Suzdaltsev, V.V. \& etc. (1965). Ocherk istorii Kharkovskogo elektromekhanicheskogo zavoda [History of the Kharkov Electromechanical Plant]. Vol. 2: 1918-1964 gg. Kharkov: Prapor [in Russian].

Tkachenko, S.S. (2006). Vnesok P.P. Kopniaieva u rozvytok vitchyznianoi elektrotekhniky [Contribution of P.P. Kopnyaev to the development of domestic electrical engineering]. Abstracts of Papers: Aktualni pytannia istorii nauky i tekhniky. Kyiv, 45-48 [in Ukrainian].

Tverytnykova, O.Ye. (2007). Rozvytok merezhi pidhotovky kadriv dlia elektrotekhnichnoho promyslovoho kompleksu [Development of a training network for the electrotechnical industrial complex]. Visnyk Natsionalnoho tekhnichnoho universytetu «KhPI»: Avtomatyka ta pryladobuduvannia, 37, 90-93 [in Ukrainian].

Tverytnykova, 0.Ye. (2008). Naukovo-doslidna robota v haluzi elektropryvodu v Kharkivskomu elektrotekhnichnomu instytuti (30-40 roky XX st.) [Research work in the field of electric drive at the Kharkov Electrotechnical Institute (30-40 years of the twentieth century)]. Abstracts of Papers: $A k$ tualni pytannia istorii nauky i tekhniky. Kyiv, 98-100 [in Ukrainian].

Tverytnykova, 0.Ye. (2009). Vnesok uchenykh Kharkivskoho tekhnolohichnoho ta elektrotekhnichnoho instytutiv u rozvytok elektrotekhnichnoi haluzi Ukrainy (1885-1950 rr.) [The contribution of scientists of the Kharkov Technological and Electrotechnical Institutes in the development of the electrotechnical industry of Ukraine (1885-1950)] (Candidate's thesis). Kharkiv [in Ukrainian].

Vasilev, M.P., Potresov, V.E. \& Teitel, I.V. (1922). Promyshlennost Ukrainy v 1921 godu [Industry of Ukraine in 1921]. Kharkov: USNKh [in Russian].

Volosnyk, Yu.P. (2002). Nova burzhuaziia Ukrainy ta rozvytok pryvatnopidpryiemnytskoi diialnosti na finansovomu rynku $v$ roky $N E P u$ [The new bourgeoisie of Ukraine and the development of private entrepreneurship in the financial market during the NEP]. Kharkiv: NMTs «SD» [in Ukrainian].

Vydolob, Yu.F. \& Senko, V.I. (1998). Kafedra teoretychnykh osnov elektrotekhniky [Department of Theoretical Foundations of Electrical Engineering]. Fakultet elektroenerhotekhniky. Narysy istorii, Kyiv: KPI, 53-75 [in Ukrainian]. 
Ihor Annienkov

(National Agricultural Agricultural Library of the National Academy of Agrarian Sciences of Ukraine, Kyiv, Ukraine)

e-mail: goalan93@gmail.com

ORCID: https://orcid.org/0000-0002-6642-8048

\section{Formation of the First School of Electric Machine Engineers in the Ukrainian SSR (the 1920s)}

The development of electrical engineering in the Ukrainian SSR against the background of implementing electrification since the second half of the 1920s began in the absence of both specialized engineers and their training system. But, by the 1930s the Republic managed to create its own school of electric machine engineers, the primacy leadership in which was not finally determined by researchers and was ascribed either to Kharkiv Technological Institute (KhTI) or to Kharkiv Electromechanical Plant (KhEMZ). However, the scientific works in which such allegations were made were territorially limited to Kharkiv region. This did not exclude the possibility of establishing a different course of real historical events in the expansion of the territorial boundaries of purposeful research. Thus, the controversial and fragmentary coverage in the historiography of the establishing of the first school of electric machine engineers in the Ukrainian SSR made its clarification relevant for research on the history of Ukraine within the selected chronological boundaries.

However, in addition to the purely historical aspect, the relevance of the theme is determined by the possibility of studying the experience gained in the organization of rapid training of engineers for knowledge-intensive industries in conditions of the urgent need for them, and with the lack of current experience of such work. In this context, the results of the study acquire extrapolation features, and this makes them useful in conditions similar to studied. Thus, the goal of this study is to determine the regional and professional formats of the first Ukrainian school of electric machine engineers and the reasons that led to their formation. As a result of studying the issue, it is concluded that the first school of engineers of electric machines in the Ukrainian SSR was organized in 1930 in the VTNZ (Technical Institutions of Higher Education) at KhEMZ. The reasons for organizing the studied school in Kharkiv were both in the crisis of the industry in the early 1920s and the measures taken by the USSR government to overcome the crisis territory after territory, with the additional implementation of the industrial production concentration policy in general. As a result, the regional electric machine-building facilities inherited for Ukrainian SSR from the Russian Empire lost their perspective and, accordingly, the need for engineering staff. KhEMZ, as the most powerful profile plant in the USSR, fully complied with the government's concept of industrial development, and that fact determined its further progress and, consequently, the growth of regional needs for engineers. The main reason for the organization of systematic training of electric machines engineers at the industrial enterprise was the practice of direct borrowing of appropriate construction schemes from leading foreign manufacturers introduced in the second half of the 1920s. As a result of the application of this variant of scientific support, Ukrainian manufacturers had gained priority access to modern design construction methods, which allowed them to speed up the process of proper personnel training significantly. The process became even faster when the students themselves were involved in the performing of mentioned borrowings, which, against the background of the urgency of the problem with engineering staff, played a key role in the organization of the appropriate school directly at the enterprise.

Keywords: electrical engineering, electrification, engineering staff, industry, school 